\title{
Roman Conception of Self and Others
}

\author{
Ruochuan Xu \\ Correspondence: Ruochuan Xu, International Department, the Affiliated High School of South China Normal University, \\ Guangzhou, China. E-mail: xuruochuan@163.com
}

Received: September 18, 2018

Accepted: October 4, 2018 Online Published: October 25, 2018

doi:10.5539/res.v10n4p139

URL: https://doi.org/10.5539/res.v10n4p139

\begin{abstract}
This paper discusses ancient Romans' auto-stereotypes and hetero-stereotypes, which are respectively the way they identified themselves and other peoples. Organized thematically, the sections center around the thesis that stereotypes were influenced by and in turn influenced Rome's historical development. They unfold to address virtus and benevolent conqueror as two major auto-stereotypes and Greeks as a major group to which major hetero-stereotypes directed. The essay refers to primary texts in an attempt to reveal the psychology behind stereotypes, and points out their dynamic nature. Its major arguments are that virtus and the conception of justice in conquests both had stabilizing effects on Rome's politics; the evolution of Roman view towards Greece reflects manipulation of individuals as well as historical contexts.
\end{abstract}

Keywords: Rome, Greece, stereotypes, justification, virtus

\section{Introduction}

Starting as a small town founded allegedly by Romulus in 753 B.C.E., Rome grew steadily among its stronger neighbors, notably Etruscans to the north and Greek immigrants to the south. Partly by the resilience of Roman soldiers and partly by their successful assimilations in initial conquests, Rome grew into a Mediterranean empire seven centuries later; having assimilated Etruscans, subjugated Carthage, and stepped onto Greece, Rome in its Late Republic was still meeting new peoples - perhaps including Antony's famous affair with Egyptian queen Cleopatra VII.

Encounters brought stereotypes. While stereotypes can never be accurate when narrowed down to every member of the groups they describe, they are rooted in certain defining characteristics of different groups, and constitute an important means through which people make sense of themselves and the outside world. "Making sense" here both means giving past events an explanation, and contributing to future judgments. In the world of ancient Romans, frequent contact with and conquests of diverse cultural groups provided a fertile soil for auto- and hetero-stereotypes, among which are the Romans' concept of virtus, self perception as clement conquerors, and adoring yet anxious attitudes towards Greece.

These stereotypes should not be viewed as static or independent. Various Roman auto- and hetero-stereotypes influenced one another and were often created or exploited by Romans to justify collective or individual actions. The significant question to ask about Romans' stereotypes is not how much of them are based on facts, but how the selection of facts is reflective of and influential in the Romans' world and their conceptions. This essay will briefly discuss representative Roman stereotypes, their relationships, and their implications.

\section{Virtus in Roman Political Life}

\subsection{Origin and Representation of Virtus}

The prototypical Roman virtue, virtus in Latin, is one of the oldest and most frequently cited Roman auto-stereotypes. Evoking masculine strength, virtus originally meant courage on the battlefield. As a newly-emerged city-state, Rome in its early Republic stage selected soldiers from its citizens to battles that were not so much concerned with expansion as self-preservation; in this context, a typical Roman was a farmer-soldier, and his contribution to the state was his virtus, expressed as valor in war. This core spirit of virtus is a central theme in Aeneid, Virgil's (2007) epic of the Roman past, or more accurately justification of the Roman present. When Anchises gives his final words to Aeneas in the underworld, he reminds his son to take his virtus as an example: "Oh, for his [Anchises's] righteousness, oh, for his old-fashioned honor, his right hand/ Never defeated in war! No man would have lived if he'd challenged/ Him to a fight...." Virtus as an auto-stereotype was involved in a reproductive cycle: because Rome survived with Romans' bravery, virtus was identified as a central Roman trait, and through speeches and writings such as Aeneid, influenced future generations. According to Greek historian Polybius (1889), who lived in second century B.C.E. and witnessed Rome's road to dominance, a major section of public funeral in Rome is the praise of the deceased's virtus (Polybius, 1889, book 6.53). The emphasis of virtus 
in state events like this helped set up role models for young Romans and demanded them to frame their conducts accordingly, thus passing on this auto-stereotype.

\subsection{Evolution of Virtus}

As a central word in Roman identity and political life, virtus developed with the Republic to include qualities of justice, temperance, and prudence in addition to courage. The new intellectual light of virtus was perhaps most championed by Sallust (2010), who in his preface of Catiline's Conspiracy wrote:

We use the mind more for control, the body for servitude; the one we have in common with the gods, the other with the beasts. And so I think it more upright to seek glory with their inner resources than with our physical strength and, since life is itself brief, to make the memory of our lives as long as possible. I say this because the glory of wealth and physical beauty is fluid and fragile; but virtue[virtus] is held brilliant and eternal. (Sallust, 2010, book 1.2-1.4)

While Sallust is justifying his decision to write history with virtus, the extended use of this auto-stereotype, also frequently mentioned by Cicero, was not a rare case. As the Republic grows, rhetoric at Rome was not less important than might in the field, and elites no longer saw serving in the army necessary to achieve fame and gloria.

\subsection{The Essence of Virtus}

Worth noting is that in either primitive or developed contexts, virtus almost always emphasized public contribution instead of private dominance. Contrasted to core words for "manliness" in most other cultures, virtus stands as a peculiar one that has no sexual implication. "Masculinity" in modern English, for instance, includes "sexually assertive" as one of its connotations. This peculiarity cannot be simply read as the product of Romans' selfless devotion to the state. In any society, family acts as crucial building blocks; it was just that patriarchy was so strong and inherent in laws in Roman society, that Romans needed not to stress private manliness in words. Thus, virtus as an auto-stereotype was institutionalized, the institution being the republic, and was hence enabled to play a central role in Roman political life (McDonnell, 2006).

\section{Benevolent Conqueror-or Not?}

\subsection{Romans'Self-Justification}

The need of anchoring themselves to a justified cause loomed large when Romans conquered other peoples, stimulating their auto-stereotype as benevolent and lawful conquerors to develop. Cicero (1913), in his On Duties (De Officiis), established a set of principles on which Romans' subjugation of other groups were based. He described war as a secondary means to resolve disputes when they cannot be settled through peaceful negotiations. Not only did he assert that Romans always followed this principle before starting a war, but he also prided on Romans' benevolence: "Not only must we show consideration for those whom we have conquered by force of arms but we must also ensure protection to those who lay down their arms and throw themselves upon the mercy of our generals" (Cicero, 1913, book 1.11). It is true that the Republic in its early stage generally adhered to this principle of lenience, and it was a major reason for Rome's success as Rome granted citizenship to Etruscans, Umbrians, among other groups. By Late Republic, however, Rome's wars were increasingly imperialistic in nature and less fair in procedure and aftermath.

\subsection{A Religious Perspective}

In addition to seemingly fair tenets of war, Romans enhanced their understanding of their conquests with religion. Roman generals often attributed the outcomes of battles to the power of Gods and performance of certain rituals; even more interestingly, Romans saw military victory as necessarily linked to religious victory. During its war with Etruscans, when the siege of Veii was on the verge of an end, dictator Camillus considered at once not the disposal of the enemy, but of the enemy's god, and so invited, "Juno Regina, you who now inhabitants of Veii, I pray that you will follow us as victors to our city, soon to be your city, where a shine worthy of your majesty will receive you" (Livy, 1850, book 5). Part of Camillus's reason for doing so was the belief that any state would be defenceless and null without the protection of its own gods, and transferring the Etruscan Juno was synonymous with military triumph. Romans went beyond the conception that "our gods helped us" in its deep-rooted view of religious subjugation and assimilation as integral parts of war. In this religious perspective, Romans saw their conquests as just because of gods' help and clement because of their welcome of other peoples' gods. In this way, Rome was less anxious about its expansion.

\subsection{Fulfillment of Auto-stereotype}

Roman political decision and perception of history usually attempted to fulfill the self-image as clement and legitimate conquerors - an important way in which this auto-stereotype was exploited. As can be next seen, Romans' achievement of their ideals is sometimes discrepant between appearance and content. Take the Third Punic War as an example: it was preluded by Numidia's encroachment of Carthaginian territory, two years after which Rome declared war on Carthage 
when Roman envoys discovered Carthaginian possession of army and navy. Carthage offered hostages and other concessions to appease Rome, but Rome gathered the army and further demanded conditions of peace. As Rome issued increasingly harsh terms, its final demand that Carthage destruct its current city and build a new one further inland enraged Carthaginians to sought to arms (Livy, 1850, book 48). While it seems that it was Carthage that provoked the war and Rome followed the principled procedure to war just as what Cicero laid out centuries later, Rome's offering of cruel peace treaties was already an act of war. Its pretext of gathering the army was Carthage's possession of new army and navy, which supposedly violated the peace treaty made after the Second Punic War; yet by that time, Carthage had paid all the required indemnity and viewed the treaty as null. Rome's motive in using harsh conditions to provoke war might not be too different from later Europeans - to set themselves in a rightful position. No wonder Polybius (1889) observed:

This idea having been firmly fixed in the minds of all, they looked out for a suitable opportunity and a decent pretext to justify them in the eyes of the world. For indeed the Romans were quite rightly very careful on this point. For instance, the general impression that they were justified in entering upon the war with Demetrius enhances the value of their victories, and diminishes the risks incurred by their defeats; but if the pretext for doing so is lame and poor the contrary effects are produced. (Polybius, 1889, book 36.2)

Polybius suggests that superficially just procedures of war were created for utility, namely ensuring the soldiers' morale. Even when they were not on the just side, the power of Romans' auto-stereotype as just could direct them to look for pretexts and deceive themselves. Romans were so obsessed with the lawfulness of their conquests with reason.

\subsection{Impact of Self-justification}

If the procedure is just, then the outcome must be just. As modern historian David Mattingly (2011) suggests, the concept of justified and benevolent conqueror is more than mere self-justification, particularly when taking into consideration Roman writings on the clemency and justice shown to defeated enemies and new subjects. Virgil's, Cicero's, and others' works gave Roman elites assurance that their colonial rule was just and divine. Reality was distorted at times when Romans recognized the enemy's legitimate activities as offence of their interests (Mattingly, 2011, p.18). This anxious reaction, or even ideology, of colonizers can be compared to the nineteenth century concept of "White Men's Burden," whereby Europeans saw their colonization as beneficiary to indigenous peoples by spreading advanced knowledge and technology. We must not ignore the self-deceptive aspect of this Roman auto-stereotype, given that tricks lurked behind the façade of just war and inequalities clearly defied the picture of equal citizenship for all.

\section{Rome and Greece-Shift of Stereotypes}

\subsection{Greek, Roman, or Greco-Roman?}

Rome's interaction with Greece, as a classical example of cultural merger, brought about interaction among Romans' and Greeks' auto- and hetero-stereotypes; as the story went, the development of Romans' auto-stereotype was influenced by its hetero-stereotype of Greece first as antithesis and then as cultural forefather. When people refer to the culture of the antiquity, the term "Greco-Roman" frequently comes to mind. Horace's (2011) famous quote that "Conquered Greece took prisoner her rough conqueror and introduced/ The arts to rustic Latium." (Horace, 2011, book 2 epistle 1 lines 156-157) outlines the basic Greek influence of Rome and points to the origin of the concept people have of a Greco-Roman cultural entity.

\subsection{Initial Roman Setting of Greece as Antithesis}

Yet the historical development has more nuances. Initially, Greek influence, or Hellenic influence, was not so welcomed in Rome, especially by Cato the Elder. In his famous admonishments for his son to be careful of Greek literature and medicine, as well as other writings and speeches, Cato's central concern was that infiltration of Greek culture might corrupt the simplicity of Romans. A stringent advocate of the typical Roman virtus, Cato took a tough stance against luxuries and spread of Hellenic culture, and hence earned a name as Cato the Censor. Ironically, Cato himself spoke Greek and read more than a small amount of Greek literature. In Cato, the anxiety to juxtapose one's own culture with that of the influential other was clearly exhibited. This tendency is perhaps best illustrated in a famous part of Aeneid, in which Virgil (2007) invokes this archaic juxtaposition:

Others [Greeks] will hammer out bronzes that breathe in more lifelike and gentler

Ways, I suspect, create truer expressions of life out of marble,

Make better speeches, or plot, with the sweep of their compass, the heaven's

Movements, predict the ascent of the sky's constellations. Well, let them!

You, who are Roman, recall how to govern mankind with your power.

These will be your special "Arts": the enforcement of peace as a habit, 
Mercy for those cast down and relentless war upon proud men. (Virgil, 2007, book 4 lines 847-853)

Through setting a contrasting hetero-stereotype of Greeks as artists, Romans affirmed their auto-stereotype as simple, courageous, and clement conquerors. Interestingly, Greek contemporaries of Cato generally viewed Romans as barbarians, and Cato had that in mind when he wrote:

They have taken an oath amongst themselves to kill all barbarians with their medicine, but they do this only for a fee so that they may be trusted and may bring ruin the more easily. They often refer to us, too, as barbarians and they defile us more foully than they do others by calling us "Opikoi". (as cited in Henrichs, 1995, p. 247)

From this perspective, Romans' so-called projected auto-stereotype, or the Greek stereotype of them that they learnt about, also contributed to the dynamic evolvement of Roman identity. When Romans came aware of Greeks' perception of them as barbarians in a cultural sense, they would not appreciate it and would try to rebel against Greeks' low opinion of them, hence be inspired to build their auto-stereotype on a separate ground, to champion the virtue of their deeds against Greece's intellectual brilliance.

\subsection{Assimilation}

Cato's belligerent view of Greek culture didn't last long, as Hellenistic artworks entered residences of the Roman elite, and as Roman politicians, fostered under a Hellenized education system, made regular use of Greek rhetoric. A dramatic exhibition of Greek influence on Romans can be seen in Scipio Aemilianus's burst into tears when he won the Third Punic War and looked at the burning Carthage. Accordingly, he quoted lines in Illiad, "the day shall be when holy Troy shall fall /And Priam, lord of spears, and Priam's folk," in a sublime realization of and concern for the mutability of human affairs and fate of nations (Polybius, 1889, book 34). Cato would not approve let alone understand Scipio's reaction if he witnessed this scene: how could a Roman general who just gave Rome's biggest enemy a final blow, not be indulged in the sweetness of victory, but instead shed tears for it? Such a universal concern typical of Greek culture took hold of Scipio over the traditional Roman vision of state interest at hand.

\subsection{Polyvalent Stereotypes}

Yet even with the adoption of Greek culture, Roman view of Greece in the Late Republic was still ambivalent, or to use a better word, polyvalent. On one hand, Greece as a source of civilization and intellectual and artistic paradigms was widely acknowledged; on the other, contemporary Greeks were after all subjects fallen to the Roman army, and were often recognized as degenerated. This hetero-stereotype would not stay unexploited by politicians. Cicero, while praising Greece, especially Athens, as an inspiration to Rome in a letter to his brother Quintus, utilized Romans' unpopular image of contemporary Greeks to denigrate his political rival Piso, revealing that Piso often held licentious banquets with drunken Greeks (Cicero, 1891, section 22). In Cicero's case, the selection of polyvalent stereotype seemed only to be a matter of expedience, not of true opinion. Yet important to note is his dichotomous picture of Greek culture and Greeks in his time, which was shared by many other Romans. When Sulla captured Athens in 86 B.C.E., he annihilated the population but maintained the city buildings, in his reverence for past Greek greatness. In Late Republic period, the decline of Greek city states, even in relation to Hellenistic cities such as Alexandria, was an irretrievable trend. Greek existence came to be more dominant in a cultural sense, and both Romans and Greeks found it necessary to reconcile their auto- and hetero-stereotypes in the new context. The traditional polar view of Roman deeds and Greek words and arts was not lost, except that now Roman accepted Greece as its cultural "conqueror" and Greeks accepted Rome as its physical one. Greek historian Dionysus of Halicarnassus (1937), in his Roman Antiquities, approves Roman practice of granting citizenship to conquered peoples and establishing colonies on conquered lands and criticizes Greek emphasis on birth and despise of foreigners. When Dionysus concedes on Romans' superiority in conducts but stresses their Greekness in culture, he gave fellow Greeks a justification of Roman superiority over them (Dionysus of Halicarnassus, 1937, book 2).

\section{Conclusion}

Stereotypes always have some to do with the reality, yet they have everything to do with human attempt to rationalize one's relation to the world. Since "self" and "others" can often reflect each other, auto-stereotypes and hetero-stereotypes cannot be separated. Rome championed their stereotypes of themselves as possessing virtus and benevolence to the conquered, in this way separating themselves with other peoples and forming unique identities. These stereotypes are partial truth, but they provided Romans with guidance and assurance through writings and practices that reflect them.

Stereotypes in the Roman world constantly engaged with historical progresses, and while part of these evolutions could be recognized as collective trends, such as a more open Roman attitude towards Greece, some were pushed by personal concerns of a few elites. For example, when Cicero discussed virtus as something relevant only to the individual, he downplays the original familial glory associated with this word to better promote himself as a novus homo, a new man 
in the senate. Under his influence, virtus as an important carrier of Romans' auto-stereotype left traces on other Romans with its new meaning. This might be a way in which words can be dangerous. When privileged writers leave their words behind within historical and personal contexts, the late-comers would not always consider these circumstances and instead add their own bias when interpreting the already "biased" source. It is in this manner that Tacitus's Germania became a Bible for Nazis, when some extracted the "noble" qualities of German ancestors out of Tacitus's dispassionate silhouette under zeal of nationalism (Krebs, 2012). The power of stereotypes is inevitable, and sometimes convenient, yet its flaws must always be taken care of as people use them to judge themselves and others.

\section{References}

Cicero, M. T. (1891). Against Piso. In The orations of Marcus Tullius Cicero chapter 10 section 22. (C. D. Yonge \& B. A. London, Trans.). York Street, Covent Garden, London: George Bell \& Sons. Retrieved from http://www.perseus.tufts.edu/hopper/text?doc=Perseus\%3Atext\%3A1999.02.0020\%3Atext\%3DPis.\%3Achapter\% 3D10\%3Asection\%3D22

Cicero, M. T. (1913). On duties book 1section 11. (W. Miller, Trans.). London: William Heinemann Ltd. New York, NY: G. P. Putnam's Sons.

Dionysius of Halicarnassus. (1937). Roman antiquities book 2 chapter 16. (E. Cary Trans.). Cambridge, MA: Havard University Press. Retrieved from http://penelope.uchicago.edu/Thayer/E/Roman/Texts/Dionysius_of_Halicarnassus/2A*.html

Henrichs, A. (1995). Graecia Capta: Roman Views of Greek Culture. Harvard Studies in Classical Philology, 97, 243-261. https://doi.org/10.2307/311309

Horace. (2011). Epistles book II epistle I lines 156-157. (J. Davie Trans.). Oxford, UK: Oxford University Press

Krebs, C. B. (2012). A Bible for National Socialists. In A most dangerous book: Tacitus's Germania from the Roman Empire to the Third Reich. W.W. Norton.

Livy, T. (1850). History of Rome by Titus Livius: The epitomes of the lost books, book 5 and 48. (W. A. McDevitte Trans.). York Street, Covent Garden, London: Henry G. Bohn. Retrieved from http://www.perseus.tufts.edu/hopper/text?doc=Perseus\%3Atext\%3A1999.02.0150\%3Abook\%3D48

Mattingly, D. J. (2011). From Imperium to Imperialism. In Imperialism, power, and identity: Experiencing the Roman Empire. Princeton, NJ: Princeton University Press.

McDonnell, M. A. (2006). The Boundaries of Manliness. In Roman manliness: Virtus and the Roman Republic. Cambridge, UK: Cambridge University Press, 2006.

Polybius. (1889). Histories, book 6, 34, and 36. (E. S. Shuckburgh Trans.). London: Macmillian. Retrieved from http://www.perseus.tufts.edu/hopper/text?doc=Perseus:text:1999.01.0234

Sallust. (2010). Catiline's Conspiracy book 1.2-1.4. (W. W. Batstone Trans.). Oxford, UK: Oxford University Press.

Virgil. (2007). Aeneid book 4 and 6. (F. Ahl Trans.). Oxford, UK: Oxford University Press.

\section{Copyrights}

Copyright for this article is retained by the author(s), with first publication rights granted to the journal.

This is an open-access article distributed under the terms and conditions of the Creative Commons Attribution license (http://creativecommons.org/licenses/by/4.0/). 